\title{
ASSESSMENT OF THE ADAPTIVE REUSE OF CASTLES AS MUSEUMS: CASE OF CYPRUS
}

\author{
D. MISIRLISOY \& K. GÜNÇE \\ Eastern Mediterranean University, Faculty of Architecture, Cyprus
}

\begin{abstract}
Military establishments, including castles, fortresses, military posts and towers, were mainly constructed for defence purposes. The conservation of military structures as well as other heritage buildings is important since they are monuments that represent a sense of identity, and national pride, bearing a message of oppression. The only way to sustain these monuments is re-functioning with an appropriate approach since they have already lost their original function. However, the problem is to select the most appropriate function according to the structural and formal characteristics of the monuments.

The study aims to question the success of the adaptive reuse projects in terms of appropriateness of the museum function and its implementation in castles. Generally, there is a tendency to convert old castles into museums. Due to the physical characteristics, museum can be accepted as a compatible function, if museums are designed with correct approaches. Otherwise, the heritage buildings will lack a living function and become disused or abandoned. The study is a comparative research among castles located in Cyprus and converted to museums. Four castles of the castles in Cyprus that have been converted to museums have been evaluated and compared in terms of the use of military establishments as museums. The selected castles were evaluated in two parts with defined criteria: firstly, in terms of conservation principles and secondly, in terms of museography.

According to the results, generally the adaptive reuse projects have sustained the cultural identity of the heritage buildings; however, they have failed in bringing about efficient use and achieving socio-cultural benefits. Although structures have been preserved physically, most of them lack a living function and visitors. Existing exhibitions should be supported by other exhibitions or activities to attract more visitors. Also, successful museum design approaches around the world should be observed and analysed. Then, the existing museums should be re-designed.

Keywords: adaptive reuse, castle, conservation, cyprus, museography.
\end{abstract}

\section{INTRODUCTION}

An appreciation began to emerge from the mid-19th century onwards that heritage buildings are precious and should be preserved. Adaptive reuse is one of the possible conservation strategies and often is the most preferred over others, such as preservation, restoration and rehabilitation [1]. Adaptive reuse includes any activity that conserves the physical fabric and the evidence of a structure or site, while accommodating new uses. The adaptive reuse of architectural heritage that can no longer be used for its original function also requires design creativity [2]. Adaptive reuse helps to regenerate an area in a sustainable manner, as well as transforming heritage buildings into accessible and usable places [3]. It poses quite difficult challenges for designers since changing the function of a heritage building may introduce new regulatory conditions [4].

Within this context, this article evaluates the compatibility of museum function for castles and its museum approaches. In the study, all the castles in Cyprus have been observed and listed. Their location, construction date, physical condition and new use have been identified. Then, those castles, which have been converted into museums, have been analysed in depth in terms of conservation and museography. In totally, there are 10 castles in Cyprus, four of which have been converted to museums. 


\section{THEORETICAL BACKGROUND}

\subsection{Classification of military establishments}

The conservation of military structures as well as other heritage buildings is important since they are monuments that represent a sense of identity and national pride, bearing a message of oppression. The only way to sustain these monuments is re-functioning since they have already lost their original function. There is an intense conflict between the preservation of the original structure and all its later interventions [5]. Military establishments can be categorized differently in various sources. Latham [5] divides military establishments into two groups: castles and bases. However, fortifications and observation towers can be also accepted as military establishments. Thus, in this study, the following classification has been made as: castles, fortifications, military bases and observation towers.

Castles are complex structures that are used for defensive and administrative purpose. Mostly, castles also provide a residence for the king, his family and their servants. Fortifications can be defined as walls and structures that are built around a city or region for defensive purposes. Sometimes they are combined with the castles. Castles and fortifications are evidence of the former social structure, the state's economy and the culture [6]. Military bases are not magnificent and unique buildings like castles, but they symbolise major conflicts. Bases are generally huge complexes, which comprise working institutions and accommodation for thousands of personnel with all the amenities of community support [6]. Observation towers are the structures that have been built mostly on top of mountains or next to the sea to protect the city from enemies. They can be constructed attached to a castle or a military post; they can also be freestanding structures.

2.2 Conservation vs. museography in adaptive reuse of military establishments as museum

There are two important aspects in adaptive reuse of military establishments as museum that must be taken into consideration. Conservation approach of the heritage building is one of these aspects.

The existence of international charters and standards guide us in the process of conservation of heritage buildings. These charters and standards point out international criteria for the preservation of built cultural heritage.

The Venice Charter is one of the most significant charters, which includes two articles regarding new additions in heritage buildings. Article 5 states that "The conservation of monuments is always facilitated by making use of them for some socially useful purpose. Such use is therefore, desirable but it must not change the lay-out or decoration of the building. It is within these limits only that modifications demanded by a change of function should be envisaged and may be permitted" [7]. On the other hand, Burra Charter introduces that: "Conservation is based on a respect for the existing fabric and should involve the least possible physical intervention. It should not distort the evidence provided by the fabric. The traces of additions, alterations and earlier treatments on the fabric of a place are evidence of its history and uses. Conservation action should tend to assist rather than to impede their interpretation. New construction work, including infill and additions, may be acceptable, provided: it does not reduce or obscure the cultural significance of the place" [8].

Another crucial charter, The Secretary of the Interior's Standards for Rehabilitation [9] assert that: "New additions, exterior alterations, or related new construction shall not destroy historic materials that characterize the property. The new work shall be differentiated from 
the old and shall be compatible with the massing, size, scale, and architectural features to protect the historic integrity of the property and its environment".

These articles may help introducing clear criteria, which help in preservation of built cultural heritage. They also point out international evaluation criteria that help us evaluate case studies in different context and produce better strategies in decision-making process of adaptive reuse projects.

The other aspect in adaptive reuse of military establishments as museum is museography approach of the museum project. Contemporary museum making is challenging, creative, complex and collaborative activity in the 21 th century. It is also multidisciplinary, multifaceted and as complex as the variety of exhibitions which deals with many professional practices from curation to design and from architecture to theatre and film [10].

Museology and museography, which are the most important aspects of museum making, are always mixed up with each other. 'Museology' is broadly used as a term of reference based on the ideas of theoretical inquiry. 'Museography' is museology's more down-to-earth, practically minded sibling [11]. The critical and theoretical examination of the museal field is museology, whereas museography encompasses the practical aspects.

Museology can be simply defined as the study of museums, their history and underlying philosophy, their unspoken aims and policies, and their educative or political or social role [12]. On the other hand, museography is a field that fundamentally contributes to the collection, conservation and protection of a significant part of the movable cultural heritage. In essence, museography deals with the practical features of museums such as accessibility to the museum, circulation, display of art pieces, aspects of the museum lighting, climate control, collection security and flexibility [13].

Aspects like organization of displays, circulation or lighting for exhibits are important for successful museum design. On the other hand, projects adapting heritage buildings into museums may create more challenges for both designers and museographers, because important concerns for conservation and museography should be taken into consideration together [13]. Military structures were mainly constructed for defence purposes; so the rationale behind the construction results in similar characteristics among military buildings such as introverted organization and solid facades. For these reasons, generally it is preferable that castles are converted into museums. Although museum functions are appropriate for castles, there are many aspects of conservation and museography, which create challenges for the designer. There could be a conflict between the aspects of conservation and museography in the adaptation process of the architectural heritage (Table 1).

In a museum, one of the most important aspects is accessibility. The entrance is noticeable and accessibility of the building from the city should be well defined. The circulation route in the exhibition spaces should be well designed; on the other hand, protection of the art pieces should be provided. Appropriate lighting should be used for exhibits; this could be natural or artificial lighting; however, natural lighting should not be reflected directly onto the art pieces so as not to harm them. Correct room temperature should also be maintained for the protection of exhibits [13]. Furthermore, the building should be integrated with the city. For a successful adaptation, the heritage building should not be accepted as a single object, its surrounding and neighbourhood should also be considered. The new function of the building should be appropriate so as not to harm the architectural heritage. New interventions should respect the history and originality of the building. As indicated in different charters, new additions should be reversible and distinguishable. Appropriate materials should be used to preserve the authenticity of the building [13]. 
Table 1: Conservation versus museography [13].

\begin{tabular}{ll}
\hline & Aspects of museography and conservation \\
\hline Museography & Conservation \\
\hline Accessibility & Location and integration with the city \\
Circulation & Appropriateness of the new function \\
Organization of the display & Respect for building's history \\
Aspects of museum lighting & Respect for originality of the building \\
Climate control & Reversibility of the additions \\
Collection security & Legibility of additions \\
Flexibility for temporary exhibitions & Use of appropriate materials \\
\hline
\end{tabular}

\section{METHODOLOGY}

The method has three objectives. Firstly, questionnaires have been done with the visitors of the castles; also number, profile, nationality and age intervals have been introduced. A total 200 questionnaires (50 for each castle) have been conducted with the visitors in different days. The questionnaire basically, includes two parts. The first part consists of questions for the museography aspects and the second part includes conservation aspects of the castles. It is asked to answer the questions as 'YES', 'NO' or 'NOT SURE' and the results have been calculated in percentage, and then have been discussed.

Secondly, observations have been done through site survey. Selected castles have been visited in order to observe the current condition of the castles after conversions. Approaches in using a castle as a museum and also the level of the interventions have been questioned.

Thirdly, a successful example from another country which were converted from castle to museum have been observed and investigated in order to compare it with analysed case studies and to introduce better management practices. At the end, all collected data have been analysed and discussed.

\section{AN OVERVIEW OF CASTLES IN CYPRUS}

Cyprus is the third largest island in the Mediterranean Sea. It occupies a key position in the Eastern Mediterranean. The island was described by Benjamin Disraeli as "the key to Western Asia" [14]. Cyprus has one of the richest and most fascinating histories of Europe and the Middle East. As the result of being an island and having a strategic location, Cyprus had been occupied by different civilizations throughout history.

In 1974, the island was divided into two sectors as: the Northern Cyprus where Turkish Cypriots live and the Southern Cyprus where Greek Cypriots live. This demographic composition of Cyprus is the result of its long and turbulent history. Cyprus became a focus of interest between various people and states of different cultures and religions because of its geographical location and strategic importance. These civilizations include: Byzantines (395-1191), Lusignans (1192-1489), Venetians (1489-1571), Ottomans (1571-1878), and British (1878-1960) [15].

Many cultures have lived on the island and following every period of occupation, the island has changed its socio-economic and socio-cultural structure. In this respect, multiculturality 
is the most important aspect in the architecture of Cyprus. The island has successfully preserved its rich cultural heritage, despite changes in its socio-economic, economic and political structure. Despite the changing societal mosaic on the island, traditional architectural traces can still be found [16]. The architecture of the island has been affected by all of these factors. Since the island faced many attacks throughout history, different castles were built to defend the island from its enemies. In this respect, castles and fortifications are important elements of the architectural heritage of the island. Three of the castles were built on top of the mountains as observation towers for keeping a watch on the enemies before they came closer to the island. The other seven of them were built next to the sea for defensive purposes. In Cyprus, there are 10 castles in total, which are listed in Table 2.

The 10 castles of Cyprus have been observed and listed, and four of them, which have been converted to museums, have been analysed in depth. The study is a comparative research. Four castles that have been converted to museums have been compared in the following section in terms of the use of military establishments as museums.

\section{EVALUATION OF THE CASE STUDIES}

After 1974, the island was divided into two sectors as: the Turkish North and the Greek South. Today, five of the listed castles (Bufavento, Kantara, Othello, Kyrenia and St. Hilarion) lie in the northern part, while five (Kolossi, Larnaca, Limassol, Paphos and Saranta Colones) are in the southern part of the island. Four of the castles that were converted into museums were selected as case studies and have been analysed in depth.

Table 2. Overview of castles in Cyprus.

\begin{tabular}{|c|c|c|c|c|c|}
\hline & $\begin{array}{l}\text { Name of the } \\
\text { castle }\end{array}$ & City & $\begin{array}{l}\text { Construction } \\
\text { date }\end{array}$ & $\begin{array}{l}\text { Physical } \\
\text { condition }\end{array}$ & $\begin{array}{l}\text { Current } \\
\text { function }\end{array}$ \\
\hline 1 & $\begin{array}{l}\text { Bufavento } \\
\text { Castle }\end{array}$ & Kyrenia & 11th century & $\begin{array}{l}\text { Partly } \\
\text { demolished }\end{array}$ & No function * \\
\hline 2 & Othello Castle & Famagusta & 14th century & $\begin{array}{l}\text { Under } \\
\text { renovation }\end{array}$ & $\begin{array}{l}\text { Art and cultural } \\
\text { centre }\end{array}$ \\
\hline 3 & Kantara Castle & Famagusta & 10th century & $\begin{array}{l}\text { Partly } \\
\text { demolished }\end{array}$ & No function * \\
\hline 4 & Kolossi Castle & Limassol & 13th century & Renovated & No function * \\
\hline 5 & Kyrenia Castle & Kyrenia & 7th century & Renovated & Museum \\
\hline 6 & Larnaca Castle & Larnaca & 12th century & Renovated & Museum \\
\hline 7 & $\begin{array}{l}\text { L i m a s s o l } \\
\text { Castle }\end{array}$ & Limassol & 12 th century & Renovated & Museum \\
\hline 8 & Paphos Castle & Paphos & 13th century & Renovated & $\begin{array}{c}\text { Cultural activity } \\
\text { centre }\end{array}$ \\
\hline 9 & $\begin{array}{l}\text { Saint Hilarion } \\
\text { Castle }\end{array}$ & Kyrenia & 10th century & Renovated & Museum \\
\hline 10 & $\begin{array}{l}\text { Saranta Ko- } \\
\text { lones Castle }\end{array}$ & Paphos & 7th century & Ruined & No function * \\
\hline
\end{tabular}

*Open to visitors as a monument 


\subsection{Description of the case studies}

Kyrenia Castle has an organic shape with four bastions in each corner, having a huge courtyard in the middle. The castle is located in the city centre, next to Kyrenia harbour, which is one of the most important tourist attraction points of the city. St. Hilarion is located on top of the mountains for protection from Arab attacks. Although the location is far from the city centre, a great number of tourists and locals visit the castle. There are illustrations in the castle which represent castle life of the time. Although the castle is quite big, there are just four small exhibition rooms: an introduction section to the castle, an illustration of a buttery and Lusignan kitchen, an illustration of the castellan and soldiers, and also a workshop space, which carries a display of how the maintenance and repair of weapons was carried out in the Lusignan period. There is a cafe and souvenir shop in the castle so that you can get some rest in the castle hall and enjoy the beautiful scenery of Cyprus.

Larnaca Castle is located next to the sea and has a strategic point in the city centre. The castle was constructed to protect the harbour of the town and consists of two historic layers. The southern part of the structure was built during the Lusignan period and the two-storey building part located in the northern half is an Ottoman structure. The castle is unique among the other nine castles located on island in terms of having a part that possesses Ottoman architectural characteristics. Limassol Castle is located in the historic city centre and its purpose was to guard and protect both the port and the city itself. The archaeological evidence indicates that it existed during the Byzantine period; however, the structure underwent some changes during the Lusignan and Ottoman periods. Today, the castle houses the Medieval Museum of Cyprus (Fig 1).

\subsection{Visualization and discussions of questionnaire results}

50 questionnaires have been conducted for each castle. Firstly, visitor number and profiles of the castle have been defined. Then, various questions about conservation and museography of the castle have been asked.

The number of the visitors for Kyrenia Castle is approximately 90 people per day. $80 \%$ of these visitors were tourists from different countries such as Turkey, United Kingdom, Russia, German, etc. The percentage of the local people that visit castle (20\%) is quite low when compared with the tourists. $43 \%$ of the visitors are at the $45-64$ age intervals $65 \%$ of them are high-school level.

On the other hand, number of the visitors for St. Hilarion Castle is 60 for each day; however this number increases especially in the weekends. $41 \%$ of the visitors were locals and $59 \%$ of them were Turkish, British, Russian, etc. 55\% of the visitors are at the 35-44 age intervals $55 \%$ of them are high-school level.

Thirdly, around 40 people visit Larnaca Castle each day. $26 \%$ of the visitors are local and $74 \%$ is tourists from different countries such as Greece, United Kingdom, Russian, German, etc. $38 \%$ of the visitors are at the 35-44 age intervals $59 \%$ of them are high-school level.

Lastly, the number of the visitors for Limassol Castle is 80 for each day. $19 \%$ of the visitors were locals and $81 \%$ of them were tourists. $34 \%$ of the visitors are at the $45-64$ age intervals $61 \%$ of them are high-school level.

\subsection{Observation of the case studies through site survey}

Despite the advantages of the location, the Kyrenia Castle is not well integrated with the city. All the museums in the castle are permanent exhibitions and this situation causes the number 


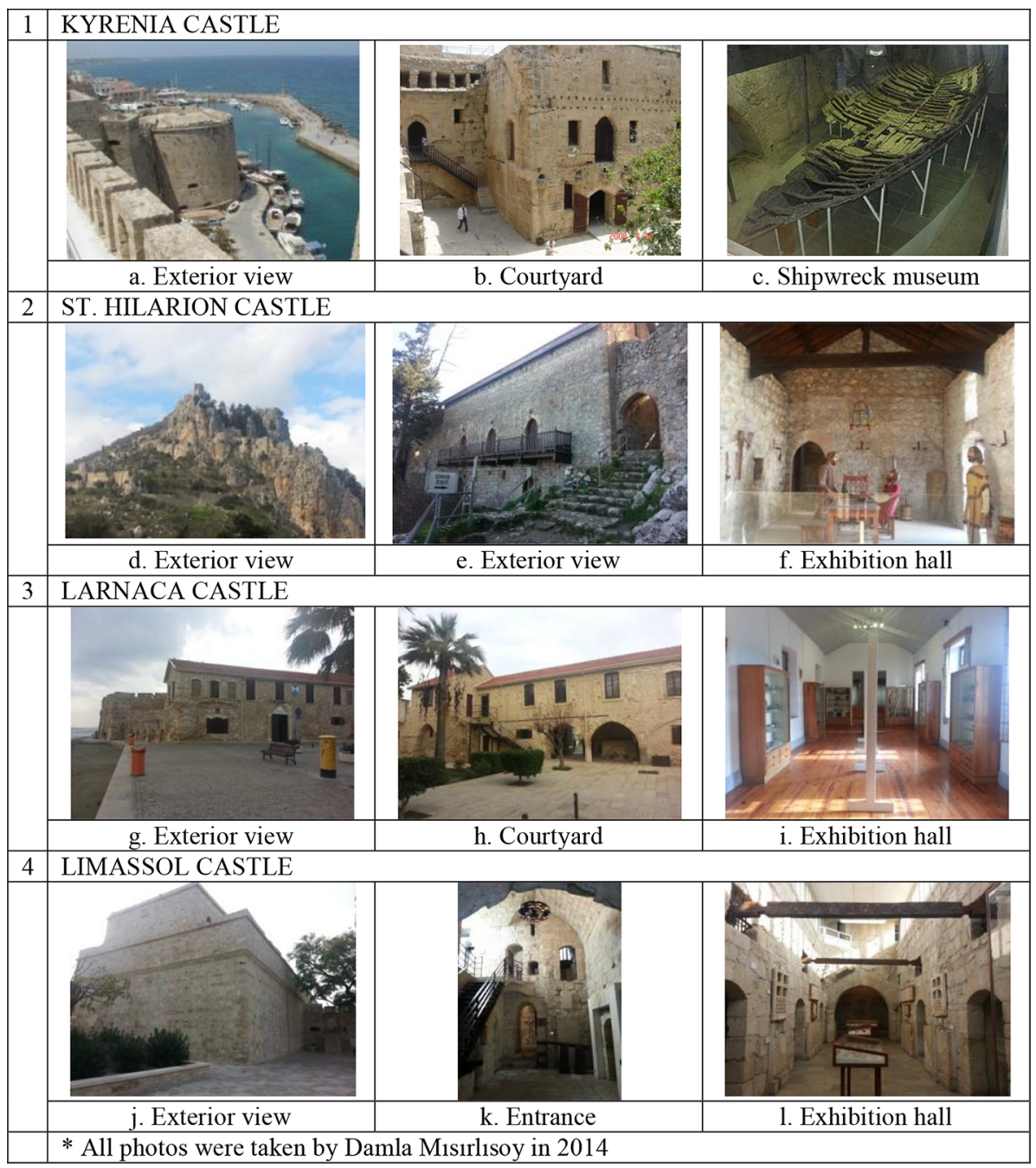

Figure 1: Visual media of selected case studies.

of local visitors to decrease. Local people visit the museum once and never go again. Although some activities are organized in the courtyard such as music concerts, the courtyard is so huge and is not well- designed that these activities are not enough to enable the castle to survive from its lack of a living function. The museum should be supported by temporary art exhibitions and activities to attract local people as well. The museum opened in 1976 and since that time no interventions have been made to the museum. Although the old history of the structure has been well preserved until today, the design of the museum should be rethought with a more contemporary approach. There was some rehabilitation work during restoration but no later additions have been made to the structure. Kyrenia Castle only has access from the harbour by a bridge; however, it is not a visible and welcoming entrance. Since it was constructed for the purpose of protection from enemies, the castle has a solid facade without openings. This creates problems for the structure as a functioning museum. 
Table 3: Visualization of questionnaire result.

\begin{tabular}{|c|c|c|c|c|c|}
\hline \multicolumn{6}{|c|}{ Visitor characteristics } \\
\hline Criteria & & Kyrenia & St. Hilarion & Larnaca & Limassol \\
\hline \multirow[t]{2}{*}{ Profile } & Local & 20 & 41 & 26 & 19 \\
\hline & Tourist & 80 & 59 & 74 & 81 \\
\hline \multirow[t]{8}{*}{ Nationality } & Turkish Cypriot & 18 & 40 & 3 & 2 \\
\hline & Greek Cypriot & 2 & 1 & 23 & 17 \\
\hline & Turkish & 33 & 43 & 0 & 0 \\
\hline & Greek & 0 & 0 & 17 & 23 \\
\hline & British & 27 & 6 & 25 & 19 \\
\hline & Russian & 11 & 4 & 12 & 17 \\
\hline & German & 5 & 0 & 7 & 4 \\
\hline & Other & 4 & 6 & 13 & 18 \\
\hline \multirow[t]{2}{*}{ Sex } & Male & 54 & 63 & 61 & 56 \\
\hline & Female & 46 & 37 & 39 & 44 \\
\hline \multirow[t]{4}{*}{ Age intervals } & $18-34$ & 18 & 34 & 24 & 29 \\
\hline & $35-44$ & 37 & 55 & 38 & 31 \\
\hline & $45-64$ & 43 & 11 & 31 & 34 \\
\hline & $65+$ & 2 & 0 & 7 & 6 \\
\hline \multirow[t]{4}{*}{ Education level } & High school & 65 & 55 & 59 & 61 \\
\hline & University & 30 & 35 & 34 & 32 \\
\hline & Master & 5 & 9 & 7 & 5 \\
\hline & $\mathrm{PhD}$ & 0 & 1 & 0 & 2 \\
\hline
\end{tabular}

Aspects of museography and conservation

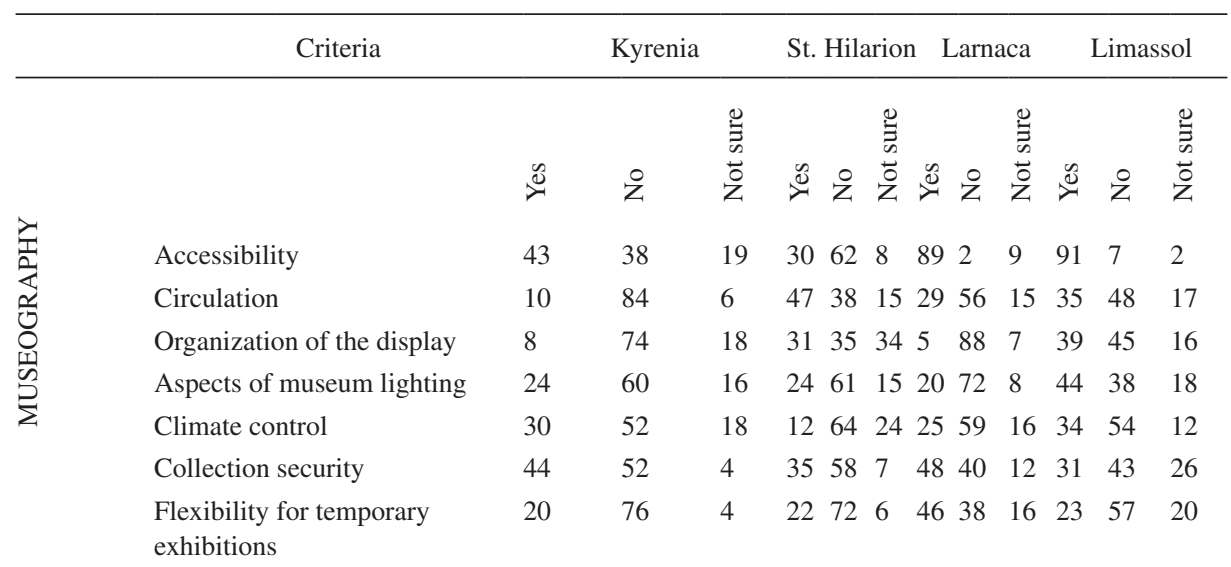


Table 3: Continued.

\begin{tabular}{|c|c|c|c|c|c|c|c|c|c|c|c|c|c|}
\hline \multirow{7}{*}{ 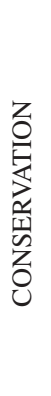 } & $\begin{array}{l}\text { Location and integration with } \\
\text { the city }\end{array}$ & 41 & 58 & 1 & 16 & 62 & 22 & 76 & 23 & 1 & 85 & 12 & 3 \\
\hline & $\begin{array}{l}\text { Appropriateness of the new } \\
\text { function }\end{array}$ & 88 & 4 & 8 & 76 & 21 & 3 & 84 & 12 & 4 & 89 & 2 & 9 \\
\hline & Respect for building's history & 92 & 8 & - & 87 & 2 & 11 & 94 & 6 & - & 92 & 2 & 6 \\
\hline & $\begin{array}{l}\text { Respect for originality of the } \\
\text { building }\end{array}$ & 84 & 12 & 4 & 65 & 34 & 1 & 74 & 16 & 10 & 78 & 13 & 9 \\
\hline & Reversibility of the additions & 64 & 10 & 26 & 56 & 29 & 15 & 70 & 13 & 17 & 67 & 10 & 23 \\
\hline & Legibility of additions & 72 & 24 & 4 & 45 & 29 & 26 & 56 & 21 & 23 & 54 & 21 & 25 \\
\hline & Use of appropriate materials & 74 & 20 & 6 & 26 & 45 & 29 & 12 & 65 & 23 & 28 & 48 & 24 \\
\hline
\end{tabular}

Note: All graded over 100

As a result of the solid facade and the limited number of openings, in general artificial lighting is used to light the exhibits. Although the castle is quite big, the exhibitions are not large enough when compared with the scale of the building. Circulation is not well-defined and collection security is inadequate.

Four small exhibition rooms are not enough for the castle. Although it is a good approach to illustrate the old life of the castle, this could be supported by additional exhibitions. Also, the exhibitions should be re-designed with a contemporary approach. Although it is huge, the circulation route in the castle is well defined. The finishing materials used during the rehabilitation process are not compatible with the old structure. The castle has lacked maintenance since its rehabilitation.

Today, the castle used as the District Medieval Museum of Larnaca. There are some ceramic works and weapons, which are exhibited in the museum. The exhibition in the northern part of the building should be re-designed with a more contemporary approach in terms of exhibition elements, panels and lighting (Fig. 1). Some pieces of art are being exhibited to visitors in the open air courtyard. This is not a correct approach in terms of conservation of movable heritage; weather conditions can damage the art pieces. Also, additional activities and exhibitions should be arranged to sustain the museum's function in the castle.

Physically, the castle has successfully preserved until today as a museum; however, the circulation route is not well defined within the museum. The structure has limited openings on the facade. In this respect, the museum lighting should be re-designed. New added structures including stairs have been designed with wooden material in order to catch the harmony with the style, and also they are reversible and legible from the old. The materials and structures used for exhibits are not suitable for a contemporary museography approach. The castle has a solid facade and limited openings on the facade; hence, it has an introverted organization. It has a huge garden with a strategic location, in which social and cultural activities can be organized. Thus, the museum could be more integrated with the city and the neighbourhood.

\subsection{Investigation of a successful example in best management practises: Castelvecchio Museum in Verona}

Castelvecchio Museum in Verona consists of complex of buildings, which have been built in different times, courtyards, gardens, and towers of the Scaliger castle. It is situated next to the river Adige, which runs through the centre of Verona. It is connected to the other side of the 
river with a bridge that marks the line of the historic wall, which surrounded the city and divided the castle into two: On the eastern, city side was the fortified garrison and on the other, the residential palace (Fig. 2). It was built from the 1st to the 18th century and renovated between 1957 and 1964. The museum was designed to house a collection of sculptures, paintings and artefacts about the city and the surrounding area from the 12th to the 18th century. The most important piece was a sculpture that had acquired an important symbolic value for the city, a statue of one of the original members of the family (Cangrande I), seated upon a horse [17].

The aim of the project was to understand historical and contextual qualities and then to apply a new contemporary layer of value and consequence to the building. This project was a revolutionary approach in 1950s and even today it is one of the greatest examples of remodelling projects [17].

The museum is perfectly integrated with the city in terms of its location, new use and also with the collections exhibited in the museum. The new function respects the history and the originality of the building. The interior of the museum has been designed with a contemporary style. The materials, colours and exhibiting elements are in harmony with the historic building and at the same time can be differentiated from the old. The castle consists of different parts that have been built in different periods; however, new additions are legible and have been built with appropriate materials. The museum also is well-designed in terms of circulation, lighting and organization of displays.

The conversion is not only successful in terms of conservation and museography approaches but also successful in terms of management practises as well. The reason to visit the castle is not just its rich collections, also the building itself as an object. These two aspects make the conversion successful and sustainable in terms of management.

\subsection{Findings and discussions}

When observation results compared with the questionnaire results, it can be seen that they support each other. In general, there is a tendency to use castles as museums because of the physical characteristics. Castles are usually built for protection purposes, so facades are solid with limited openings and plan layouts have an introverted organization, generally with a courtyard in the middle. Although the museum function is appropriate for the castles physically, conservation and museography aspects should be considered in conjunction.

Conservation plans, heritage enhancement programs and signage systems are quite successful; the castles lack the existence of proper management plans in adaptive reuse projects

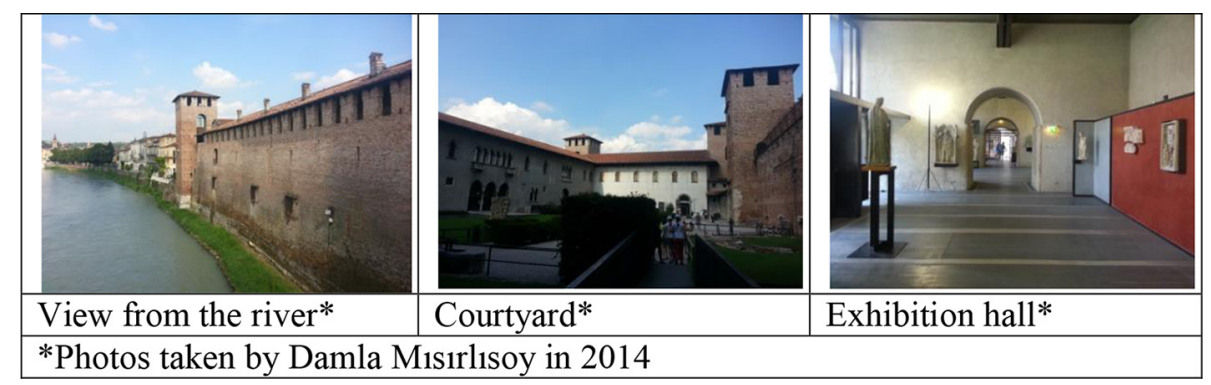

Figure 2: Visual media of Castelvecchio in Verona, Italy. 
and its sustainability for the future use. As Worthing and Bond [18] states "A conservation plan, in order to be effective, needs to be accompanied by a second stage- the 'management plan'. The management plan should be carried out separately. The final two-stage document, however, must read as one entity, as neither part has any real value unless both are completed in an integrated manner."

The museums should make their profits for the updates and rehabilitation works of the castles. The museums could be re-designed, collections can be improved and then entrance fees can be increased. If the visitors should believe that the exhibition would answer their expectation, they will pay more for the entrance. Then, this profit can be invested to the development of the museums. Although the entrance fee of Castelvecchio Museum is $€ 10$, the museum attracts great number of visitors every day. On the other hand, for the Limassol and Larnaca Castle the entrance fee is $€ 2.50$ and for the Kyrenia and St. Hilarion is almost $€ 3.00$. Unfortunately, despite the lower entrance fees castles do not attract enough visitors.

One of the important considerations in conservation of heritage buildings is ownership and management of the monuments. As mentioned before, Cyprus is a divided island into two sectors and two of the introduced castles are in the South and two of them are in the North. For the ones in South ownership belongs to Department of Antiquities and for the North is Department of Antiquities and Museums. Although there are two different authorities and policies of two different sectors, the approaches are quite similar as seen in the questionnaire results as well.

Another important issue that affect the conservation and adaptive reuse of heritage buildings are addition designs. In the adaptation process of heritage buildings, new additions can be required for two reasons: to meet the needs for new function or to create structural, aesthetic and functional missing parts. Design approaches of additions in heritage buildings are a commonly discussed issue in the conservation field. Preserving the qualities of the existing building and being respectful to the existing is important in design of additions for heritage buildings [19]. For the all castles, additions should be designs to meet the needs of the new function if it is needed. As seen in the Castelvecchio example, additions can respect and can help to promote the building as a monument as well.

\section{CONCLUSION AND PROPOSALS}

The article examined the adaptive reuse of castles as museum in Cyprus. In order to question the success of a museum in a historic building, it is not enough to evaluate it only in terms of conservation principles. The concerns about museography are also crucial to sustain the proposed function of the building. For a sustainable heritage adaptation, buildings should offer economic, socio-cultural and environmental benefits to the users. Community participation is needed for adaptation projects to be sustainable.

According to the results, generally the adaptive reuse projects have sustained the cultural identity of the heritage buildings; however, they have failed in bringing about efficient use and achieving socio-cultural benefits. Although in general structures have been preserved physically, most of them lack a living function and visitors. Existing exhibitions should be supported by other exhibitions or activities to attract more visitors. Also, successful museum design approaches around the world should be observed and analysed. Then, the existing museums should be re-designed.

In Cyprus, the most important problem regarding the conservation of heritage buildings is the lack of professionals that are expert on a specific subject. In this case, there were no 
experts, which have enough experiences on museography. The adaptation of architectural heritage is a complex and challenging process. The solutions depend on the creativity of the designer; however, the correct approach involves the collaboration of the designer, restoration experts and museographer.

\section{REFERENCES}

[1] Elsorady, D.A., Assessment of the compatibility of new uses for heritage buildings: The example of Alexandria National Museum, Alexandria, Egypt. Journal of Cultural Heritage, 15, pp. 511-521, 2014. http://dx.doi.org/10.1016/j.culher.2013.10.011

[2] Ames, D. \& Wagner, R., Design and Historic Preservation: The Challenge of Compatibility, Rosemont Publishing: Maryland, 2009.

[3] Bullen, P.A. \& Love, P.E.D., Adaptive reuse of heritage buildings. Structural Survey, 29(5), pp. 411-421, 2011. http://dx.doi.org/10.1108/02630801111182439

[4] Langston, C., Wong, F.K.W., Hui, E.C.M. \& Shen, L.-Y., Strategic assessment of building adaptive reuse opportunities in Hong Kong. Building and Environment, 43(10), pp. 1709-1718, 2008. http://dx.doi.org/10.1016/j.buildenv.2007.10.017

[5] Latham, D., Creative Re-use of Buildings Volume II, Donhead Publishing: London, 2000.

[6] Petre, J.S., Crusader castles of Cyprus: The fortifications of Cyprus under the Lusignans:1191-1489, Phd Thesis, Cardiff University, UK, 2010.

[7] ICOMOS, Venice Charter, International Charter for the Conservation and Restoration of Monuments and Sites, available at http://www.icomos.org/charters/venice_e.pdf, 1964 (accessed June 2014).

[8] Australia ICOMOS, Burra Charter, The Charter for Places of Cultural Significance [online], available at http://australia.icomos.org/wpcontent/uploads/BURRA_CHARTER.pdf, 1999 (accessed June 2012).

[9] The Secretary of the Interior's Standards for Rehabilitation, available at: http://www. nps.gov/hps/tps/standguide/rehab/rehab_standards.htm, 1979 (accessed June 2012).

[10] Macleod, S., Hanks, L.H. \& Hale, J., Museum Making: Narratives, Architectures, Exhibitions, Routledge: London, 2012.

[11] Grewcock, D., Doing Museology Differently, Routledge: London, 2013.

[12] Vergo, P., New Museology, Reaktion: London, 1989.

[13] Günçe, K. \& Mısırlısoy, D., Adaptive Reuse of Military Establishments as Museum: Conservation vs. Museography, Vol. 143, WIT Transactions on Ecology and the Environment, WIT Press, 2014, ISSN 1743-3509.

[14] Sonyel, S.R., Cyprus: The Destruction of a Republic and its Aftermath, CYREP: Nicosia, 2003.

[15] Tofallis, K., A History of Cyprus, Greek Institute: London, 2002.

[16] Günçe, K., Ertürk, Z. \& Ertürk, S., Questioning the 'prototype dwellings' in the framework of Cyprus traditional architecture. Building and Environment, 43(12), pp. 823 833, 2008.

http://dx.doi.org/10.1016/j.buildenv.2007.01.032

[17] Brooker, G. \& Stone, S., Rereadings: Interior Architecture and the Design Principles of Remodelling Existing Buildings, RIBA Enterprises: London, 2004. 
[18] Worthing, D. \& Bond, S., Managing Built Heritage: The Role of Cultural Significance, Blackwell Publishing: Oxford, 2008. http://dx.doi.org/10.1002/9780470697856

[19] Misırlısoy, D. \& Günçe, K., An Analytical Approach for Evaluation of Contemporary Additions to Architectural Heritage, RE-Cond'15: Re-Evaluating Contemporary Designs in Historical Context, Istanbul, Turkey, 22-24 July 2015. 